\title{
O DEPÓSITO DE CHUMBO, ZINCO, COBRE E PRATA DO RIBEIRÃO DA PRATA, MUNICÍPIO DE BLUMENAU-SC

\author{
GERNOT SCHIKER
}

\author{
DISSERTAÇÃO DE MESTRADO - Programa de Pós-Graduação em Geologia - UFPR \\ DATA DE DEFESA: 16/08/96
}

\begin{abstract}
O principal objetivo deste estudo é caracterizar geologicamente o depósito de chumbo, zinco, cobre e prata do Ribeirão da Prata, localizado no município de Blumenau, Santa Catarina. Foram utilizadas as técnicas de mapeamento geológico da área em que esta inserido o depósito, em associação com o mapeamento geológico-estrutural das galerias (situadas sobre o corpo mineralizado) e a caracterização petrográfica e geoquímica do minério e suas encaixantes. Desta forma, buscou-se definir o tipo do depósito do Ribeirão da Prata, e o processo mineralizador do mesmo. Características importantes do depósito mineral definidas por este estudo são: (a) o nítido controle estrutural exercido pela Zona de Cisalhamento do Perimbó sobre o corpo mineralizado. (b) a destacada atuação de processos de substituição sobre as rochas pré-existentes no falhamento do Perimbó, os quais manifestam-se através da silificação e sericitação tanto das litologias da Faixa Riberão da Prata (gnaisses e granitos) quanto dos arcósios do Grupo Itajaí. (c) a associação do processo mineralizador, responsável pela cristalização dos sulfetos, à fase principal de silicificação (geradora do quartzo Q2) e à sericitização. (d) a deformação do corpo mineralizado já constituído durante a fase inicial de deformação das rochas do Grupo Itajaí. (e) os principais elementos de minério são o chumbo e o zinco, sendo o cobre e a prata de importância secundária. Galena, esfalerita, calcopirita e pirita são os minerais de minério primários, enquanto a
\end{abstract}

covelita, a goethita, a malaquita, a azurita e, mais raramente, a cerussita e a piromorfita compõem a paragênese secundária do minério. De acordo com o que é sugerido pelos controles estruturais do depósito, o processo mineralizador está associado ao evento tectonometamórfico regional que afeta as rochas do Grupo Itajaí e que está datado em $550 \mathrm{Ma}$ (Macedo et al., 1984). Desta forma, o depósito do Ribeirão da Prata teria sido gerado no fim do Ciclo Orogênico Brasileiro. Admite-se, como processo gerador do depósito, a movimentação de fluidos hidatogênicos, portadores dos elementos de minério ( $\mathrm{Pb}, \mathrm{Zn}, \mathrm{Cu}$ e Ag) e da sílica, através da Zona de Cisalhamento do Perimbó e a substituição, devido à atuação destes fluidos, das rochas granitosgnáissicas da Faixa Ribeirão da Prata e dos arcósios do Grupo Itajaí. Depois de já estar constituído, o corpo mineralizado foi deformado por uma reativação da Falha do Perimbó associada à fase de deformação compressiva (com sentido SE para NW), responsável pela nucleação de um sistema transcorrente sobre a cobertura sedimentar representada pelo Grupo Itajaí. Desta forma, propõe-se uma conjugação dos tipos hidatogênico e estruturogênico para o depósito do Riberão da Prata, sendo as soluções hidratogênicas o agente carreador dos metais, e a zona de falha o agente canalizador destas soluções e, posteriormente, deformador do corpo mineralizado já formado através de deslocamentos reversos. 